\title{
Identifying Links between Corporate Social Responsibility and Reputation: Some Considerations for Family Firms
}

\begin{abstract}
Corporate Social Responsibility (CSR) has become a key issue for both academics and business practitioners alike. There are numerous reasons why implementing CSR policies and practices are advantageous: enhanced brand knowledge, market share, productivity, efficiency, workforce motivation and competiveness, to name a few. There are also indications that CSR practices lead to a solid, positive corporate reputation. As a result, this research aims to contribute to current literature by establishing the current state of CSR research and identifying the theoretical framework of reference for understanding the link between CSR and reputation, providing a basis for future research. We also aim to delve deeper in the specific context of family firms.

To this end-following consultations with a panel of internationally recognized scholars-a selection of leading management, marketing and ethics, corporate governance and family firm management journals were reviewed. The results - based on a content analysis of 55 articles considering the global link between RSC and reputation - allowed us to identify, among others, topics related to consumer attitude and market response to CSR activities (via brand value), along with the impact of CSR on financial value and risk management.
\end{abstract}

Keywords: CSR; Reputation; Review of the literature; Family Firms

Corresponding author: e-mail: imelero@ unizar.es

Received 26 April 2017 - Accepted 13 June 2017

This is an Open Access article distributed under the terms of the Creative Commons Attribution-Non-Commercial-No Derivatives License (http://creativecommons.org/licenses/by-nc-nd/4.0/), which permits non-comercial re-use and distribution, provided the original work is properly cited, and is not altered or transformed in any way. 


\section{Introduction}

Corporate Social Responsibility (CSR) is a topical issue in both academic research and business practice (Peloza and Shang 2011; Taneja et al. 2011; Dahlsrud 2008). During the last decade of the twentieth century and the beginning of the twenty-first century, CSR has been at the forefront of business management. Theoretically, CSR necessitates economic prosperity, social cohesion and environmental sustainability — to which a fourth dimension has been added: philanthropy (Porter and Kramer 2006). The assumption is that these actions are undertaken voluntarily, are directly related to business ethics and go beyond the existing legislation (McWilliams and Siegel 2001).

Equally, corporate reputation is founded on a series of positive and/or negative signals which allow us to anticipate how a company will behave in the future (Roberts and Dowling 2002; Janney and Gove 2011). Despite the lack of unanimity regarding the definition of this construct, one of the most widely used approaches is rooted in work by Fombrun and Shanley (1990) and Fombrun (2001), who discuss the aggregation of perceptions held by various actors in terms of how organizations respond to stakeholder demands and expectations. This approach recognizes the cumulative and informative character of such perceptions.

To date, numerous studies have examined the relationship between CSR and corporate reputation. However, a unanimous consensus is still lacking with regard to the theoretical framework. Moreover, there is no defining work that analyzes the current state of the question and identifies research opportunities. It seems pertinent then to analyze the current situation with a view to identify the theoretical framework, methodology and future lines of research into the links between CSR and corporate reputation. We attempt to develop a framework thatwhile recognizing the cross-disciplinary nature of CSR — allows researchers to delve deeper in 
the links between CSR, reputation, consumer behaviour and the financial value of the firm. In addition, we aim to take a closer look at the specific context of family businesses, with a view to delimit the most appropriate theoretical frame of reference and identify potentially interesting lines of research. This is justified by the specific characteristics of family businesses, linked to their ownership structure and management style.

This article strives to address these issues through a systematic review of the literature. To this end, we first identify the major journals in the areas of (i) business management, (ii) marketing and (iii) corporate governance and ethics. Then, we identify the most relevant articles, analyze the content of each and highlight the most relevant aspects in terms of CSR and corporate reputation, using a predefined set of search criteria.

Additionally, this article presents the results of a specific literature review in family business management journals, with a view to identify similar research patterns or the need to adapt the general framework to the family firm context. We also aim to determine the state of the issue in family business contexts (number of publications per year, topics, etc.) and to identify possible lines of future research.

The article is structured as follows: the next section explores the purpose and process underpinning our systematic review of the literature-including the search criteria used to produce auditable, repeatable results and to ensure reliability. The third section presents key findings by journal type, date, methodology and relevant topics. Section four presents the specific results for the family business context. We conclude with a discussion and conclusions section. 


\section{Systematic review of the literature}

As the work of Vázquez-Carrasco and López-Pérez (2013) indicates, the aim of a systematic literature review is to offer broad insight into existing research on a specific subject. Literature reviews use precise methods to narrow the search and evaluate each relevant study in a critical and justified manner-providing a snapshot of the major lines of investigation to date. Scholars should, therefore, execute informed decisions when researching and writing literature reviews if they are to be methodical, transparent and replicable-crucial to furthering knowledge (Peloza and Shang 2011; Tranfield et al. 2003).

The systematic review of literature is based on several assumptions. Firstly, the vast quantity of existing information should be broken down into more manageable units in order to aid understanding and management of the data. In this sense - as Rousseau et al. (2008) indicatesystematic reviews assume orderly accumulations, analyses and interpretive reflections of all the evidence provided on a specific subject; in our case, the links between CSR and corporate reputation. Through a synthesis of existing literature it is possible to identify the key articles and most interesting potential lines of future research, from the perspective of the academic community.

Literature reviews should be structured in such a way so as to permit other researchers to replicate the review process and, ultimately, produce the same results. The aim is to provide studies which are objective, transparent and synthetic; which minimize the search and analysis bias and summarize the evidence (Chan and Ngai 2011; Peloza and Shang 2011; Rousseau et al. 2008; Tranfield et al. 2003).

In general, articles are chosen on the basis of title and summary. Those articles which do not meet the selection criteria are discarded. At this point it is vital to determine the selection and 
inclusion criteria, which themselves should be structured in such a way as to ensure quality. We followed the following steps - recommended by Kitchenham et al. (2009) and Baumann et al. (2002) - in order to carry out our first review of the literature on the topic of the RSC-reputation relationship:

1. Define the research question(s): CSR and corporate reputation.

2. Use one or more keywords to execute the search in (i) a series of bibliographical databases and/or (ii) in a sample of well-defined, justified journals.

To this end, we used the results from a simple questionnaire administered to a group of carefully selected CSR researchers. Respondents were asked to list the most relevant journals covering topics in management, marketing and ethics and corporate governance (Vázquez-Carrasco and López-Pérez 2013).

3. Include the keywords: "CSR" and "reputation" in the search fields (title \& abstract) ${ }^{1}$, with no date restrictions. In this way we were able to identify those articles which investigate the CSR-corporate reputation relationship.

4. Finally, analyze the content of each of the articles selected with the purpose of identifying the theoretical framework, methodology used and potential lines of future research.

The results of this systematic literature review-including the most relevant findings and conclusions - allow us to identify the state of the research topic and can be found in the next section of this article.

\footnotetext{
${ }^{1}$ There is a significant bias toward brand image in the marketing journals. Hence, we chose to expand the search fields to find "CSR" in the abstract and "reputation" in the full text.
} 


\section{Results}

Once the most relevant journals in each of the reference areas (business management, marketing, ethics and corporate governance) had been identified, the search terms were included and an advanced search of titles was carried out. We obtained a total of fifty-five (55) $\operatorname{articles}^{2}$. Table 1 shows the articles found, listed by journal.

Table 1. Articles on the CSR-corporate reputation relationship

\begin{tabular}{|c|c|}
\hline Journal & Authors (year) \\
\hline Academy of Management Review (2) & $\begin{array}{l}\text { Aguilera et al. (2007), Mc Wiliams and Siegel } \\
\text { (2001) }\end{array}$ \\
\hline Academy of Management Journal (0) & ----- \\
\hline Journal of Management Studies (2) & Hond et al. (2014), Janney and Gove (2011) \\
\hline Journal of Management (1) & Doh et al. (2010) \\
\hline Strategic Management Journal (2) & $\begin{array}{l}\text { Godfrey et al. (2009), McWilliams and Siegel } \\
(2000)\end{array}$ \\
\hline Journal of Marketing (3) & $\begin{array}{l}\text { Brown and Dacin (1997), Chen et al. (2009), } \\
\text { Wagner et al. (2009) }\end{array}$ \\
\hline Journal of Marketing Research (1) & Sen and Bhattachrya (2001) \\
\hline Marketing Science (0) & ----- \\
\hline $\begin{array}{l}\text { Journal of the Academy of Marketing } \\
\text { Science (2) }\end{array}$ & Ellen et al. (2006), Nikolaeva and Bicho (2011) \\
\hline $\begin{array}{l}\text { International Journal of Research in } \\
\text { Marketing (2) }\end{array}$ & Du et al. (2007), Torres et al. (2012) \\
\hline Business Ethics Quarterly (1) & Van de Ven and Jeurissen (2005) \\
\hline $\begin{array}{l}\text { Corporate Governance: an International } \\
\text { Review }(0)\end{array}$ & ----- \\
\hline
\end{tabular}

\footnotetext{
2 Date of last access: December 30, 2016.
} 


\begin{tabular}{||l|l||}
\hline \hline Journal of Business Ethics (32) & $\begin{array}{l}\text { Aouadi and Marsat (2016), Axjonow et al. (2016), } \\
\text { Barnea and Rubin (2010), Bear et al. (2010), } \\
\text { Beliveau et al. (1994), Basil et al. (2009), Castelo } \\
\text { and Lima (2006), Cui et al. (2017), Dubbink et al. } \\
\text { (2008), Eberle et al. (2013), Francés and del Río } \\
\text { (2008), Harjoto and Jo (2011), Hsu (2012), Hur et } \\
\text { al. (2014), Jahdi and Acikdilli (2009), Kim (2014), } \\
\text { Kim and Park (2011), Lai et al. (2010), Lii and Lee } \\
\\
\text { (2012), Liston-Heyes and Ceton (2009), Mueller et } \\
\text { al. (2009), Pérez et al. (2015), Rettab et al. (2009), } \\
\text { Sacconi (2007), Siltaoja (2006), Stanaland et al. } \\
\text { (2011), Stuebs and Sun (2010), Tuck et al. (2007), } \\
\text { Vanhamme and Grobben (2009), Vidaver-Cohen } \\
\text { and Simcic (2015), Walker et al. (2010) }\end{array}$ \\
\hline Business Ethics: an European Review (4) & $\begin{array}{l}\text { Clarke and Gibson-Sweet (1999), Ingenhoff and } \\
\text { Koelling (2012), Jackson and Bundgard (2002), } \\
\text { Morsing and Schultz (2006) }\end{array}$ \\
\hline Business \& Society (4) & $\begin{array}{l}\text { Holzer (2008), Muller and Kolk (2015), Orlitzky et } \\
\text { al. (2011), Tetrault and Lvina (2016) }\end{array}$ \\
\hline
\end{tabular}

Source: Authors elaboration

Having analyzed the table of contents of the five leading management journals, we observed that a small body of literature - totaling seven articles — satisfied the search criteria established to analyze the CSR-corporate reputation relationship. Although no articles were found in the Academy of Management Journal, two were found in each of the following journals: the Academy of Management Review, Journal of Management Studies, and Strategic Management Journal. Finally, in the Journal of Management we found one article. We should mention here that all the studies were published after the year 2000 .

If we apply this same analysis to marketing journals the overall results are similar, with a total of eight articles being identified. In general terms, the articles analyze the consumer response to CSR actions. CSR is proposed as a direct antecedent of reputation. The Journal of Marketing stands out with a total of three articles published, while Journal of the Academy of Marketing Science and the International Journal of Research in Marketing both contain two articles in each 
journal. The Journal of Marketing Research contained only one relevant article. Marketing Science did not contain any articles that met the search criteria. In terms of date of publication, only about $25 \%$ of the articles had been published in the last five years.

In total, forty-one articles investigating the CSR-reputation relationship have been published in business ethics and corporate governance journals. The Journal of Business Ethics stands out with a total of thirty-one articles, heterogeneous in topic and content. The journals Business Ethics: a European Review and Business \& Society have each published four articles, while Business Ethics Quarterly has only published one. Corporate Governance: an International Review displayed no results. It is worth noting that almost $50 \%$ of the articles identified had been published in the last five years.

Graph 1, below, illustrates the publication time-spread for all articles identified using our systematic search process. This graph suggests we are dealing with an interesting, timely topic which has, perhaps, already reached maturity: while a peak is observed between 2009 and 2012, only $25 \%$ of the articles correspond to the last five years, as we indicated earlier. There is an increase in published work in the period spanning 2005-2008 and publication on the topic reaches its peak in 2009 with nine articles (17\% of the total sample). Between 2010 and 2012 there is a decline in articles on the relationship, which seems to mark the trend for the next five years. By 2017, however, the numbers have turned around again, with an increase in articles that abandon generalist approaches to focus on far more specific aspects such as the contribution of CSR-based reputation to the management of certain business risks. 
Graph 1. Number of articles published, by year

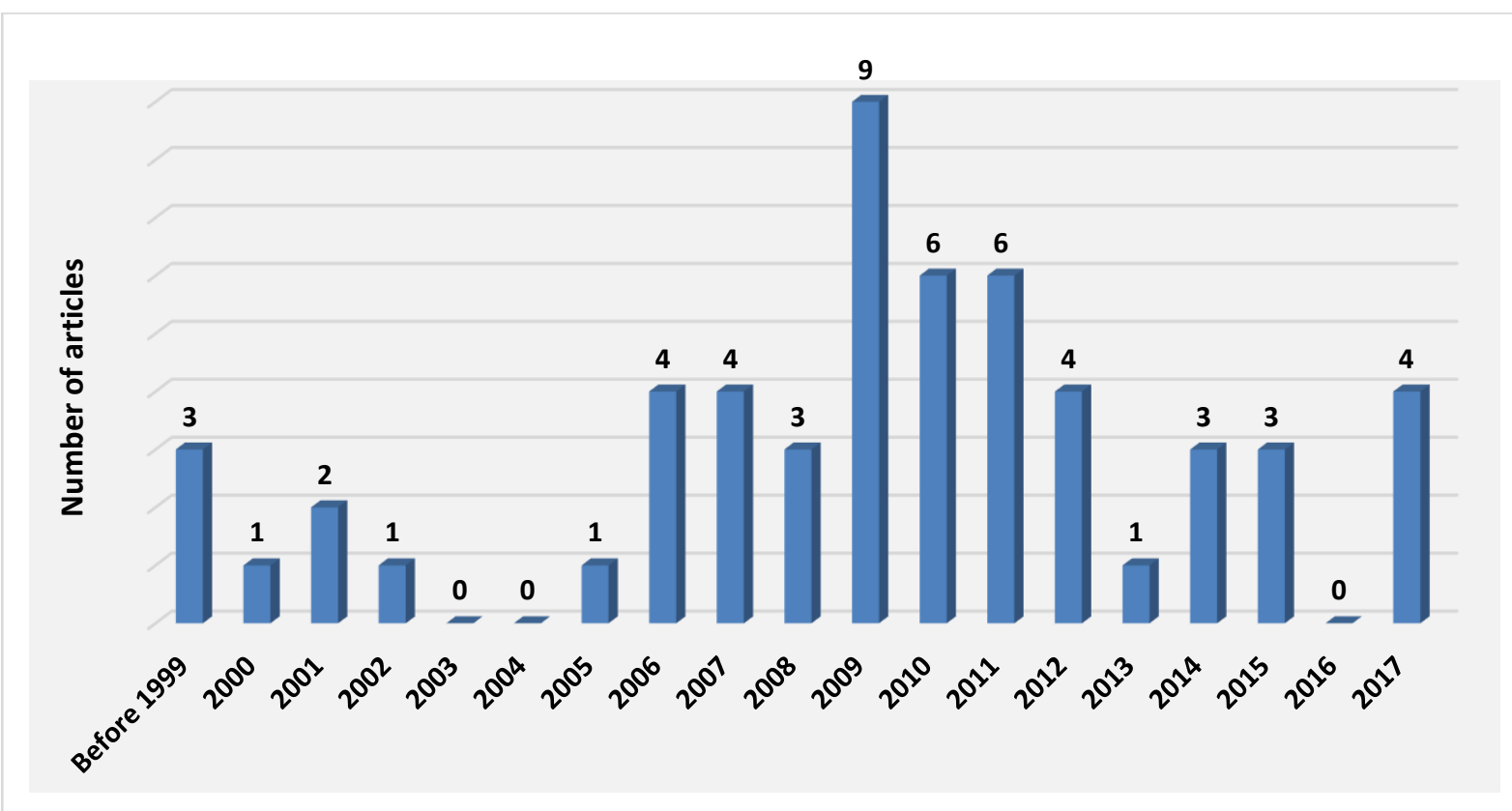

Source: Own elaboration

Broadly speaking — from a conceptual point of view_-we can conclude the following:

i) Existing management journal literature considers the CSR-reputation relationship in general contexts - the end goal being to analyze the impact of CSR on the financial value of organizations. While the variety of theoretical approaches stands out, the relationship between CSR and corporate reputation is always positive and significant. Several studies in particular (e.g., Cui et al. 2017; Doh et al. 2010; Janney and Gove 2011) consider agency problems and information asymmetry between management and stakeholders. These articles indicate that CSR-based reputation fosters a more honest organizational image, reinforcing corporate legitimacy and the trust stakeholders place in the company.

ii) Marketing journals tend to consider corporate reputation as an intangible resource of significant value, which enabling consumers to differentiate and position the company in their minds and improving the attitude of the market towards products through brand image (Brown and Dacin 1997; Torres et al. 2012). In order for CSR to reinforce corporate reputation, such 
practices must be consistent, sustainable over a long period of time and integrated at the heart of the business model (Sen and Bhattacharya 2001; Du et al. 2007; Wagner et al. 2009). Furthermore, a virtuous circle is created where by reputation once again contributes to overcoming information asymmetry and boosting the credibility of subsequent CSR actions.

iii) Finally, the papers published in business ethics and corporate governance journals are characterized by the heterogeneity of topics and theoretical approaches. A number of authors (e.g., Aouadi and Marsat 2016; Harjoto and Jo 2011; Orlitzky et al. 2011) analyze the effect of CSR on financial value; others, look at market response (e.g., Pérez et al. 2015; Stanaland et al. 2011), whilst yet others consider the importance of communication and public relations as a means of reinforcing the impact of CSR actions on reputation (Vanhamme and Grobben 2009; Morsing and Schultz 2006). Research has also been conducted to analyze the repercussion in various stakeholder groups: employees (Basil et al. 2009; Stuebs and Sun 2010), NGOs (Holzer 2008), consumers (Tuck et al. 2007) and shareholders (Sacconi 2007).

Therefore, we can conclude that the topic has sparked the most interest in business ethics and corporate governance journals ( $73 \%$ of total articles identified). At the other end of the spectrum, management journals appear to have given less quantitative importance to the subject —only $12.5 \%$; yet, in terms of qualitative research, management journals stand out for their conceptual contributions and for laying the theoretical groundwork for analysis of the CSR-reputation relationship in the remaining disciplines ${ }^{3}$. The marketing journals $(14.5 \%)$ demonstrate an important bias toward consumer behavior research.

\footnotetext{
${ }^{3}$ It should be clarified that the management journals include research on CSR in an organizational context. However, it appears that the CSR-reputation relationship has been used to analyze phenomena in a broader context. This is seen when comparing the search results for "CSR" in the title and abstract fields vis-à-vis the more specific combined search term "CSR" and "reputation".
} 
The authors have provided a summary of the content analysis and coding process in the form of a comprehensive Excel database. Following a detailed content analysis we classified the articles using the criteria shown in Table 2, explained in greater detail below.

Table 2. Summary of the content analysis (topic and methodology)*

\begin{tabular}{||l|l||}
\hline Topic & Authors (year, methodology) \\
\hline Theoretical framework & $\begin{array}{l}\text { Aguilera et al. (2007, C), Castelo and Lima (2006, C), Doh et al. } \\
\text { (2010, QT), Francés and del Rï (2008, C), McWilliams and Siegel } \\
\text { (2000, C), Mueller et al. (2009, C), Orlitzy et al. (2011, C), Pérez } \\
\text { et al. (2015, QT), Sacconi (2007, C), Tetrault and Lvina (2016, QT) } \\
\text { van de Ven and Jeurissesn (2005, C), Vidaver-Cohen and Simcic } \\
\text { (2015, QT) }\end{array}$ \\
\hline Influence in the financial value \\
of the firm & $\begin{array}{l}\text { Aouadi and Marsat (2016, QT), Axjonow et al. (2016, QT), Barnea } \\
\text { and Rubin (2010, QT), Castelo and Lima (2006, C), Hond et al. } \\
\text { (2014, QT), Doh et al. (2010, QT), Godfrey et al. (2009, QT), } \\
\text { Harjoto et al. (2011, QT), Jackson and Bungard (2002, QL), Janney } \\
\text { and Gove (2011, QT), Liston-Heyes and Ceton (2009, QT), } \\
\text { McWilliams and Siegel (2000, C) McWilliams and Siegel (2001, } \\
\text { QT), Muller and Kolk (2015), Orlitzky et al. (2011, C), Rettab et } \\
\text { al. (2009, QT) }\end{array}$ \\
\hline Consumer behaviour & $\begin{array}{l}\text { Basil et al. (2009, QT), Chen et al. (2009, QT), Clarke and Gibson- } \\
\text { Sweet (1999, QT), Cui et al. (2017; QT), Godfrey et al. (2009; } \\
\text { QT), Holzer (2008, QL), Janney and Gove (2011, QT), Kim (2014; } \\
\text { QT), Orlitzki et al. (2011, C), Stanaland et al. (2011, QT), Tuck et } \\
\text { al. (2007, QT), Vanhamme and Grobben (2009, QT), van de Ven } \\
\text { and Jeurissen (2005, C) }\end{array}$ \\
\hline Risk management & $\begin{array}{l}\text { Brown and Dacin (1997, QT), Chen et al. (2009, QT), Du et al. } \\
\text { (2007, QT), Eberle et al. (2013), Hsu (2012, QT), Hur et al. (2014, } \\
\text { QT), Jahdi and Acikdilli (2009, QL), McWilliams and Siegel } \\
\text { (2001, QT), Lai et al. (2010, QT), Lii and Lee (2012, QT), } \\
\text { Nikolaeva and Bicho (2011, QT), Stanaland et al. (2011, QT), Tuck } \\
\text { et al. (2007, QT), Sen and Bhattacharya (2001, QT), Scholder et al. } \\
\text { (2006, QT), Skard and Thorbjørnsen (2014, QT), Torres et al. } \\
\text { (2012, QT), van de Ven and Jeurissesn (2005, C), Wagner et al. } \\
\text { (2009, QT), Walker et al. (2010, QT) }\end{array}$ \\
\hline \hline
\end{tabular}

${ }^{*} \mathrm{C}=$ conceptual; $\mathrm{QL}=$ qualitative; $\mathrm{QT}=$ quantitative

Source: Own elaboration 
As a result of the analytical process an article may be coded in more than one topic area.

From a methodology standpoint, we observe a prevalence of quantitative research $(79 \%$ of the total number of articles, which represents more than $90 \%$ of the articles which include an empirical study). These studies present results by means of regressions, structural equation analysis and multivariate analysis in similar proportions. There are much fewer qualitative studies, only four articles in all: three case studies and one narrative and content analysis—only $7 \%$ of total published papers. Eight conceptual articles were identified-14\% of the total sample. These last articles were published in management and business ethics journals; none were found in marketing journals. Conceptual studies of this sort signal the current relevance of the topic and the research opportunities that still remain in the field.

\section{Key issues in research}

Described below are the main ideas emerging from the content analysis of the articles included in the sample. Various tables illustrating the specific characteristics of each of the articles are included (hypotheses, sample, results) as a basis of the content included hereafter.

\section{Definition of the theoretical framework}

The approaches used to study the CSR-reputation relationship are characterized by their diversity and lack of consensus with regard to which theoretical framework is most appropriate. This may be due to the fact that general CSR research lacks a dominant paradigm-which in turn affects the study of aspects relating to this general concept, as Orlitzky et al. (2011) indicate. In our opinion, this may be due to the fact that said relationship has been studied in a wider context. Orlitzky (2011) supports this fact inasmuch as he deems that we are still in an evolving field where varying theoretical approaches are competing with one another; and an objective consensus is still lacking to measure the absolute quality of the chosen approach. 
Siltaoja (2006) appears to share this vein of thought, recognizing that the research on reputation is characterized by a weak theoretical basis - perhaps due to the highly subjective nature of the concept itself. Hence, the debate and controversy surrounding the theoretical framework is permitted. Our review of the literature highlights the following theories:

Theory of the firm, which emerges from economic theory, assumes that one of the core objectives of any firm is to maximize profits (Barnea and Rubin 2010). Under this premise, CSR supposes a nexus between economic theory and business ethics (Jones 1995; McWilliams and Siegel 2001). CSR is considered, then, as a form of investment that can help differentiate market offerings. Products must therefore assume certain characteristics of CSR actions or specific resources be dedicated in the production process. Hence, firm opt for a market approach where CSR actions are valued. For instance, CSR helps to build and consolidate intangible attributes-like reputation-reinforcing the trust consumers place in the company and their perceptions regarding the quality of market offerings (Fombrun and Shanley 1990). CSR could thus contribute towards developing a differentiation strategy.

In order to undertake CSR actions, an adequate provision of resources is required - such as capital, work, materials and services that generate outputs (e.g., market response). Therefore, an optimum level of CSR exists, which will be determined by the cost-benefit relationship, and where the market acts as a control mechanism (McWilliams and Siegel 2001).

Agency theory: Schisms between ownership and management, coupled with incomplete information and information asymmetry, favor opportunistic behavior by agents-who may have different objectives than proprietors_-generating an agency problem.

In this context, CSR could be used by management to signal social and political commitmentat the owner's expense. The conflict arises when proprietors believe that the resources dedicated 
to CSR could boost efficiency in other areas of the organization (Friedman 1970; McWilliams and Siegel 2001; Hsu 2012; Cui et al. 2017). In any event, if proposed CSR actions coincide with owner value scales (moral case) - and are also able to strengthen competitive position (business case) - management could use CSR as a way of demonstrating how performance helps to build and consolidate reputation (Castelo and Lima 2006; Aguilera et al. 2007).

Stakeholders theory: initially proposed by Freeman (1984). This theory holds that the organization maintains relationships with diverse groups of internal and external agents-or stakeholders - who may affect or be affected by actions taken by the organization itself (van de Ven and Jeurissen 2005; Castelo and Lima 2006; Kim and Park 2011; Vidaver-Cohen and Simcic 2015; Axjonow et al. 2016; Tetrault and Lvina 2016). Therefore, the decisions taken by the organization should not only serve proprietary interests; they should take into consideration all of the reference groups as well (Jackson and Bungard 2002; Stanaland et al. 2011; Pérez et al. 2015). The need to combine these decisions with value creation in the long term is postulated. To this end, it is of the essence to strive for an interactive, mutually binding relationship fostering transparency and trust (Morsing and Schultz 2006, Torres et al. 2012). This is the theory that is most often used to explain CSR practice in business, according to McWilliams and Siegel (2001). Hence, it is proposed that CSR actions have an impact on stakeholder perceptions and judgments towards the organization, which help build corporate reputation - and ultimately help to reduce information asymmetry. Assessments of the company will be positive when stakeholders perceive consistency; but can be counterproductive if stakeholders anticipate self-interest and opportunism (Sen and Bhattacharya 2001; van de Ven and Jeurissen 2005). This approach, then, may be viewed as a natural extension of Agency Theory in terms of the relationship the organization maintains with the rest of its stakeholders. 
Resource-based theory: Companies can intuitively define themselves as an accumulation of resources. For Barney (1991), resources are defined as all of the assets, capabilities, processes, attributes, information and knowledge managed by the company. In order for an asset to be valuable it must be different, irreplaceable and difficult to imitate (Orlitzky et al. 2011; Tetrault and Lvina 2016). Under these premises, CSR helps to build and consolidate a solid, consistent, sustainable, long-term corporate reputation — which can be a source of competitive advantage to the extent that it allows the company to differentiate itself from others (Brown and Dacin 1997; van de Ven and Jeurissen 2005; Kim and Park 2011; Orlitzky et al. 2011; Stanaland et al. 2011). Due to its intangible nature, CSR-based corporate reputation becomes a key resource for understanding the competitive position of many companies. Although reputation is an asset which cannot be protected in a court of law, it does reflect the personality of the organization and-inasmuch as it is difficult to imitate-becomes a key resource for developing and maintaining sustainable competitive advantage (Janney and Gove 2011).

Furthermore, it is important to note that reputation is "built" not "bought", making it much more difficult to replicate - thus becoming an imposing entry barrier (Castelo and Lima 2006). To the extent that CSR can motivate the workforce, improve productive efficiency, facilitate access to better financial conditions and help improve the performance of the remaining organizational resources such as corporate reputation (Castelo and Lima 2006; Fombrun and Shanley 1990). Another example is the "insurance-like" approach (Godfrey 2005; Gardberg and Fombrun 2006); the notion that CSR generates moral capital which acts as a protection mechanism against negative events, while maintaining value. Authors such as Godfrey et al. (2009) and Du et al. (2007) draw attention to the fact that this moral capital serves more as a protective shield than as a value-creation resource-acting as a safety net of sorts. 
Institutional theory: The existence of a social contract between the organization and society is proposed; organizations adopt specific behaviors to access resources and gain backing from stakeholders (DiMaggio and Powell 1983). In this sense, the institutions act as intermediaries, providing guidance with regard to which behaviors are socially desirable, encouraging their development and attesting to the process by means of legitimacy (Hadani and Coombes 2015; Janney and Gove 2011; Doh et al. 2010). Legitimacy implies the assumption that company actions are adequate, desirable and appropriate in terms of societal rules, values and beliefs (Mueller et al. 2009). According to this interpretation, legitimacy helps reinforce corporate reputation, inasmuch as past actions of the firm help anticipate future actions and comparison with other companies (Orlitzky and Benjamin 2001). In other words, legitimacy reflects the acceptance of rules on the part of the company, whilst reputation differentiates firms amongst potential competitors. Given that reputation is built upon an accumulation of signals, legitimacy is necessary but not sufficient for a strong reputation (Janney and Gove 2011; Pérez et al. 2015). Under these premises CSR, (i) impacts company reputation, (ii) helps reduce information asymmetry and (iii) becomes an adequate signal for stakeholders, inasmuch as actions meet with the standards set by society and the institutions that have provided legitimacy. Interesting examples of social legitimacy include accounting reports (Clarke and Gibson-Sweet 1999; van de Ven and Jeurissen 2005), auditing firms (Dubbink et al. 2008) and external evaluation bodies (Bear et al. 2010; Doh et al. 2010) such as newspapers, financial institutions, indexes and rankings (e.g., Dow Jones Social and Sustainability Index-DJSSI).

The impact of CSR on corporate reputation

As stated at the beginning of this subparagraph, the origin of this diverse theoretical approach could signal an agency problem that exists between, (i) management and proprietors and/or, (ii) 
the company/management and stakeholders - and the way in which firms try to solve the problem of information asymmetry. In fact, much of the work analysed (e.g., Clarke and Gibson-Sweet 1999; Doh et al. 2010; Kim and Park 2011; Stanaland et al. 2011; Torres et al. 2012; Eberle et al. 2013; Tetrault and Lvina 2016) rely on not only one, but several theories to establish the theoretical framework underpinning research hypotheses. In any event, we can deduce a direct relationship between CSR and reputation, hence formulate our first hypothesis:

\section{Hypothesis 1: There is a direct relationship between CSR and corporate reputation.}

The impact of CSR on financial value

The analysis of the relationship between CSR and reputation has identified an interesting link between CSR and financial value. However, the ideas expressed in this paper should be analysed with some caution as they have been extracted from research that not only examines the aforementioned relationship but also investigates a more specific area. Hence, some key articles that have addressed this relationship may not have been included. That said, it can be assumed that achieving profit is one of the core objectives of both management and companies as a whole (McWilliams and Siegel 2001). Likewise, there is a growing demand for greater social contribution on the part of companies (Clarke and Gibson-Sweet 1999). As a result, many companies carry out CSR actions-which, in turn, should be reflected in market response. It is possible, therefore, to perceive a positive relationship between CSR and performance / financial value (Lai et al. 2010; Janney and Gove 2011; Aouadi and Marsat 2016; Axjonow et al. 2016). ${ }^{4}$ The potential contribution of CSR to streamlining internal organizational processes is highlighted: the impact on employee motivation and productivity (Rettab et al. 2009; Stuebs

\footnotetext{
${ }^{4}$ McWilliams and Siegel (2000) indicate, however, that the literature has shown the positive, negative or neutral effects of CSR on company financial performance, depending on the variables considered and the definition used.
} 
and Sun 2010; Siltaoja 2006), the implementation of more environmentally friendly, technically efficient production systems (Mueller et al. 2009; Orlitzky et al. 2011) or the obtention of better financing conditions (Doh et al. 2010; Torres et al. 2012), for example.

Furthermore, it is suggested that all companies-irrespective of their activity, size and experience-are prone to potential risks linked to operation alone. Research therefore, has focused on how CSR can aid crisis management; which, in turn, can affect a firm's competitive position. When CSR activities are in line with company activity and stakeholders-and consistent over time - they help build trust in the company and form a protective barrier which stands to be a safeguard for adverse events (Basil et al. 2009; Godfrey et al. 2009; Vanhamme and Grobben 2009; Kim 2014). This protective function can be shored up by specific communication activities, proactive behavior and, where necessary, quick response (Holzer 2008; Chen et al. 2009; Vanhamme and Grobben 2009; Cui et al. 2017). Under these premises, CSR improves the financial value of the company.

Thus, the arguments expressed in this conceptual block allow us to establish our second hypothesis ${ }^{5}$ :

Hypothesis 2: There is a direct relationship between CSR and the financial value of the company.

That being said, authors like McWilliams and Siegel (2000) report that a series of conditions must be met for the CSR-financial value relationship to be positive, namely: including company $\mathrm{R} \& \mathrm{D}$ expenditures in the analysis - considering that investment in CSR generates a degree of product differentiation and can imply certain organizational changes; taking into account the

\footnotetext{
${ }^{5}$ Appendix 1, shows a table summarizing the main articles related to this hypothesis resulting from the systematic literature review (hypothesis, sample, methodology and results).
} 
contribution of CSR to the reputation and how the various stakeholders value this; and contemplating the impact of communication - the larger the company, the greater the effect. Thus, the majority of the research analyzed in this systematic review of the literature appears to be inclined towards a positive relationship between CSR and financial value. That said, some research points to reputational value as an additional variable to be considered (e.g., Beliveau et al. 1994; Clarke and Gibson-Sweet 1999; Barnea and Rubin 2010; Doh et al. 2010; Hsu 2012; Rettab et al. 2009; Siltaoja 2006; Aouadi and Marsat 2016).

Authors such as Orlitzky et al. (2011), Janney and Gove (2011), Lai et al. (2010) or Du et al. (2007) explicitly state that one of the basic premises for CSR to positively influence financial value is that an adequate reputation amongst the reference stakeholders exists, "particularly if there are multiple competitors of varying reputation" (Janney and Gove 2011, 1565). This is due to the fact that some CSR actions are easily identified but at times it is difficult to evaluate a firm's global social performance. Authors like Doh et al. (2010) and Walker et al. (2010) indicate that some firms carry out both socially responsible and irresponsible behavior at the same time - generating information asymmetry. It is vital, therefore, to know how the market views organizational activity, particularly in terms of reputation, the social indexes, financial intermediaries — which as a whole affect market prices and, ultimately, financial performance. Furthermore, those companies which have built a solid CSR-based reputation are partially protected in the event of scandals or crises (Janney and Gove 2011; Kim 2014). The same authors indicate, however, that a reputation built on CSR must be coherent and consistent with company actions. If this is not the case, it could lead to the perception that some degree of hypocrisy exists — a schism between stated intentions and actions — which will, ultimately, have a negative impact on company value. Therefore, behavior-past actions and stated CSR 
intentions - needs to be consistent. Knowing the beliefs and values structures of the reference stakeholders, and adjusting to them accordingly, is also recommended (human rights, the environment, corporate governance, labor relations, etc.). This is crucial, as CSR activities help establish company identity—regardless of a firm's motives for implementing CSR. Company identity symbolizes how stakeholders view the firm and is reflected in the assessment and value the market places in the firm, to which CSR contributes. In order to build and consolidate a reputation that safeguards against negative situations or crises, the company must not only do the right things but promote the right values; in other words, those values the firm shares with society (Clarke and Gibson-Sweet 1999; Stanaland et al. 2011; Kim 2014). We can therefore postulate that a relationship between reputation and financial value exists ${ }^{6}$ :

Hypothesis 3: There is a direct relationship between reputation and financial value of the company.

It should be noted, however, that a series of conditions must exist for the aforementioned relationship to be sustained. Firstly, company actions must be consistent over time (Godfrey et al. 2009). Second, actions should be in line with the values and objectives of the reference stakeholders (Doh et al. 2010; Harjoto et al. 2011; Pérez et al. 2015). Last but not least, actions must be valued by the market (McWilliams and Siegel 2001). This suggests that - to the extent that CSR contributes to creating or strengthening a positive reputation - the relationship between CSR and financial performance will be positive, as stated earlier in this paper.

\section{Consumer behavior}

Authors like Brown and Dacin (1997), Sen and Bhattacharya (2001), Scholder et al. (2006), Wagner et al. (2009), Walker et al. (2010), Kim and Park (2011), Lii and Lee (2012) and Skard

\footnotetext{
${ }^{6}$ Appendix 1, shows a table summarizing the main articles with this hypothesis resulting from the systematic literature review (hypothesis, sample, methodology and results).
} 
and Thorbjørnsen (2014) indicate that a reputation built on CSR can influence consumer behavior. This is explained by the fact that CSR-based reputation helps to foster a relationship of trust between the company and its stakeholders (e.g., Stanaland et al. 2011). In specific terms, the relationship with consumers can produce a more favorable attitude toward product offerings - an enhanced perception of quality, trust - and a greater degree of consumercompany loyalty (McWilliams and Siegel 2001; van de Ven and Jeurissen 2005; Du et al. 2007; Wagner et al. 2009; Torres et al. 2012). This favorable attitude is explained by brand equity: the utility or added value the brand gives to a product (Hur et al. 2014). This is an asset of great value to companies given that it reinforces the measurable, tangible benefits of a product or service and helps differentiate knowledge and value both for the company and the customer. If the market perceives substantial differences in brand value, the company can expect to gain a competitive advantage (Lai et al. 2010; Torres et al. 2012; Hsu 2012).

In this sense, when consistency is perceived — and opportunism and hypocrisy avoided — CSR helps to spread company culture and values, which in turn contribute to an image of honesty, quality and reliability (Sen and Bhattacharya 2001; Wagner et al. 2009; Lai et al. 2010; Hur et al. 2014). ${ }^{7}$

Hypothesis 4: There is a direct relationship between reputation and brand value.

Authors like Stanaland et al. (2011), Lii and Lee (2012), Torres et al. (2012) Hsu (2012) and Eberle et al. (2013), indicate that when message consistency is reinforced by brand image activities, customer satisfaction tends to increase-in turn, leading to positive word-of-mouth which ultimately improves the competitive position of the company. All this has a positive impact on financial results (Chen et al. 2009; Lai et al. 2010; Torres et al. 2012). The literature

\footnotetext{
${ }^{7}$ Appendix 2, shows a table with a summary of the main articles related to this hypothesis, resulting from our systematic literature review (hypothesis, sample, methodology and results).
} 
indicates that a key aspect is the relationship between CSR and reputation, which itself generates positive attitudes toward the brand and shields it from possible negative events (e.g., Sen and Bhattacharya 2001; Tuck et al. 2007; Chen et al. 2009; Lai et al. 2010; Walker et al. 2010; Hsu 2012). Hence, marketing managers gain an important asset: reputational equity (Du et al. 2007; Stanaland et al. 2011). In order for this to occur, the company must keep abreast of societal values, analyze the competitive environment, integrate CSR at the heart of the organization and remain consistent over time (Sen and Bhattacharya 2001; van de Ven and Jeurissen 2005; Du et al. 2007; Lai et al. 2010). Moreover, the importance of communication is highlighted (McWilliams and Siegel 2001; Jahdi and Acikdilli 2009; Hsu 2012)—as these actions must be both visible to consumers and credible to the community (Wagner et al. 2009; Torres et al. 2012).

Other authors (e.g., Brown and Dacin 1997) indicate that-provided the company is able to differentiate itself from competitors - certain clients can be expected to be willing to pay more for products from companies that demonstrate a socially responsible attitude in line with their beliefs and values scale, (McWilliams and Siegel 2001; Sen and Bhattacharya 2001; Torres et al. 2012). Hence, we propose ${ }^{8}$ :

Hypothesis 5: There is a direct relationship between brand value and financial value of the company.

Furthermore, given that a previous hypothesis established a positive relationship between CSR and reputation, this inherently implies the effect of CSR on brand value (by virtue of reputation).

\footnotetext{
${ }^{8}$ Appendix 2, provides a table summarizing the main articles relating to this hypothesis from our systematic literature review (hypothesis, sample, methodology and results).
} 


\section{Corporate Social Responsibility and family firms}

The context that characterizes family businesses may differ from the global context defined earlier in this paper. For many of these family firms, it is important not only to maximize profits but - in many cases — to build appropriate relationships with local communities of reference and to preserve the family reputation (Van Gils et al. 2014; Cui et al. 2017). Hence, the theoretical framework of reference may need to be adapted in some way.

In order to determine the state of the question, a second literature review was carried out with the leading journals covering family businesses, small and medium-sized enterprises (SMEs), and corporate social responsibility (CSR) as our reference. The search criterion was that the articles contain the keywords "CSR" and "family firm". A total sample of eighteen (18) articles was obtained ${ }^{9}$ : among the journals covering topics relating to family business, two articles in the Family Business Review, two in the Journal of Family Business Strategy and two in the Journal of Family Business Management; among journals specializing in SMEs, three articles in the Journal of Small Business Management and one in Small Business Economics; finally, in CSR journals, six articles in the Journal of Business Ethics, one in Corporate Social Responsibility and Environmental Management and one in Business Strategy and the Environment. In the other relevant journals covering each of the three subject areas, no results were obtained. Table 3 shows our article sample, by journal and year of publication.

Both the small number of articles found and their recent dates of publication suggest that we are dealing with a topic which is currently undergoing a growth phase. As Graph 2 shows, almost $85 \%$ of the studies were published in the last five years (2013 and later). Moreover, the

\footnotetext{
${ }^{9}$ Last date of access: December 30, 2016.
} 
maximum number of articles published — a third of the total—corresponds to this year, 2017, despite the fact that the year has not yet come to an end.

Table 3. Articles analyzing CSR in family business contexts

\begin{tabular}{|c|c|}
\hline Journal & Articles (authors, year) \\
\hline Family Business Review (2) & Marques et al. (2014), Van Gils et al. (2014) \\
\hline Journal of Family Business Strategy (2) & Binz et al. (2013), Block and Wagner (2014) \\
\hline Journal of Family Business Management (2) & Aoi et al. (2015), Yusof et al. (2014) \\
\hline Journal of Small Business Management (3) & $\begin{array}{l}\text { Fitzgerald et al. (2010), Niehm et al. (2008), } \\
\text { Stoian and Gilman (2017) }\end{array}$ \\
\hline Small Business Economics (1) & Benavides-Velasco et al. (2013) \\
\hline Journal of Business Ethics (6) & $\begin{array}{l}\text { Campopiano and De Massis (2015), Cui et al. } \\
\text { (2017), Déniz and Cabrera (2005), Faller and } \\
\text { Knyphausen-Aufseb (2016), Labelle et al. } \\
\text { (2015), Zientara (2015) }\end{array}$ \\
\hline $\begin{array}{l}\text { Corporate Social Responsibility and } \\
\text { Environmental Management (1) }\end{array}$ & Laguir et al. (2016) \\
\hline Business Strategy and the Environment 81) & Block and Wagner (2013) \\
\hline
\end{tabular}

Source: Own elaboration

Graph 2. Number of articles published by year

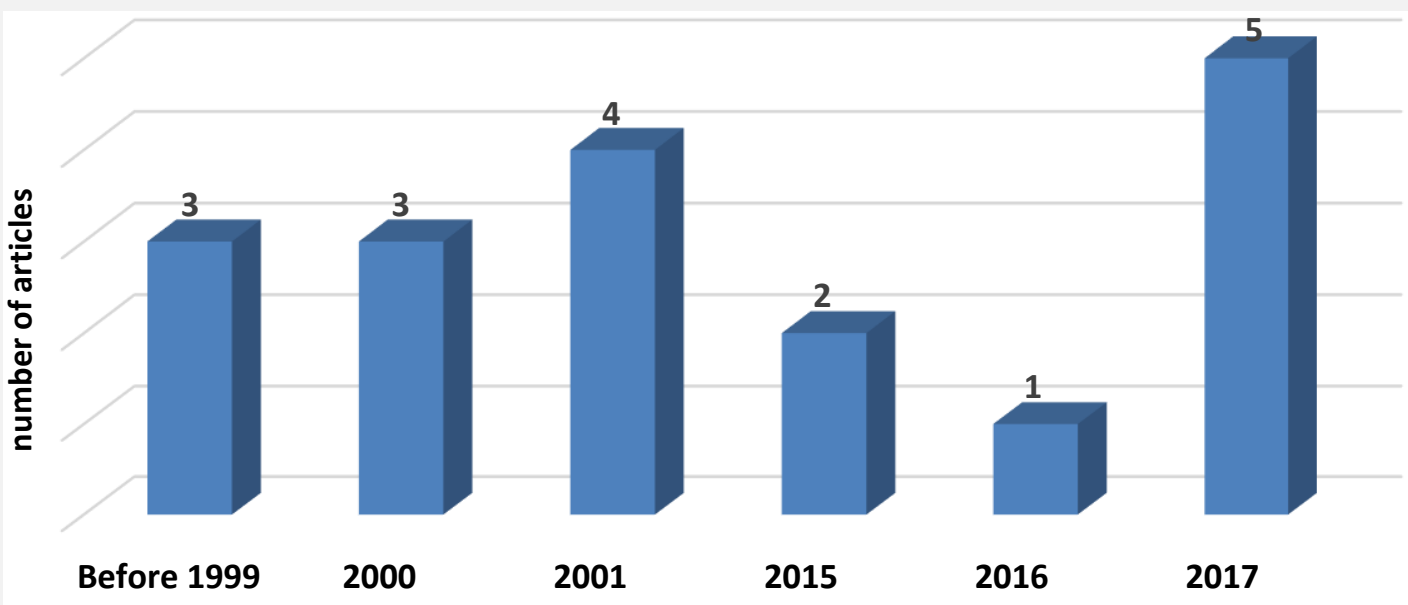

Source: Own elaboration 
In terms of content, we detect that many of these articles delve deeper into the concept of values - especially those values that define the way of being and conceiving the businesses pertaining to the family of reference. Block and Wagner (2013) are an interesting starting point. These authors indicate that family firms behave differently than non-family firms with regard to CSR, in general; although — as Déniz and Cabrera (2005) point out—we must not make the mistake of considering all family firms as a homogeneous whole in general, nor as behaving homogeneously with regard to CSR, in particular.

Several authors observe that, in general, family firms are more likely to engage in CSR actions (Aoi et al. 2015; Laguir et al. 2016; Cui et al. 2017). This may be linked to a more defined value structure and to some degree of concern on the part of family business owners regarding the reputation and brand value of their firm (Binz et al. 2013). Only Benavides-Velasco et al. (2013) indicate that family businesses are not necessarily more CSR-prone; they are, however, less socially irresponsible. As Zientara (2015) highlights, members of family firms are more likely to view business as an extension of themselves. As a result, they are more likely to avoid situations that may bring negative perceptions to their organizations.

Niehm et al. (2008), Fitzgerald et al. (2010) and Benavides-Velasco et al. (2013) conclude that family businesses tend to be very connected and committed to their local communities; a strong bond and supportive attitude that emanate from the feeling of being an active part of the community, of wanting to contribute to its development and from their awareness of the role model part entrepreneurs often play within their communities.

In this vein, studies by Marques et al. (2014) and Van Gils et al. (2014) —among otherssuggest that family businesses tend to be highly attuned to social issues, very sensitive to stakeholder interests and active in terms of philanthropy. The reason, these authors argue, has 
to do with issues of identity and image; CSR actions have an impact on company reputation. Yusof et al. (2014) point out that CSR helps small businesses preserve certain family values linked to aspects such as integrity and generosity.

It seems relevant to note that - from the perspective of the theoretical framework-none of these studies focus on the theories discussed earlier in this paper. Two theoretical approaches that fit the specificities of family businesses prevail: Stewardship Theory and Socioemotional Wealth Theory.

Stewardship Theory is rooted in the premise that the principles of Agency Theory are not always fulfilled (Marques et al. 2014). In the case of family firms, managers may not always be driven by a desire to reach individual objectives; they can take on the goals of the proprietors, adopting a collectivist approach — regardless of whether they belong to the family or not (Van Gils et al. 2014; Laguir et al. 2016, Zientara 2015). The point of reference here are the common values that both manager and proprietors (the family) share; and the manager "serves" and becomes the "guardian" of those family values.

In principle, Socioemotional Wealth connotes the emotional value intertwined with family firms that satisfies family affective needs, such as influence and affinity (Berrone et al. 2012; Labelle et al. 2015; Zientara 2015). Family members are — as a rule—-motivated by a desire to protect and preserve their socioemotional wealth (Berrone et al. 2012); hence, family members are thought to be likely to eschew any action that might imperil socioemotional wealth — which, at least theoretically, makes family firms more inclined to engage in socially responsible actions. In short, social-emotional goals and rewards—not purely economic objectives aloneare often pursued (Block and Wagner 2014; Aoi et al. 2015; Cui et al. 2017). 
Yet other authors - Van Gils et al. (2014), among others - use both theoretical approaches simultaneously.

From a methodological perspective, our review of the literature reveals a balance between qualitative research (e.g., Yusof et al. 2014; Laguir et al. 2016) and quantitative papers (e.g., Binz et al. 2013; Block and Wagner 2014; Aoi et al 2015). Compared to the popularity of the phenomenon in the general literature, however, the scarcity of studies published thus far on the family business context suggests that research in this context remains in an incipient phase. Benavides-Velasco et al. (2013) conclude that many more comparative studies are needed.

\section{Discussion and conclusions}

In carrying out a systematic review of the literature the authors aimed to carefully examine existing studies on the relationship between CSR and reputation. Specifically, we aimed to determine the state of the research in this field, the theoretical framework, methodologies used and potential lines of investigation for the future.

To this end, the authors followed recommendations by authors such as Peloza and Shang (2011), Rousseau et al. (2008) and Tranfield et al. (2003). Search criteria and journal selection were based on previous studies. Moreover, in order to assess the relevance of the topic today, no date restrictions were applied. A total of fifty-two (52) articles were found in the leading management, marketing, ethics and corporate governance journals.

Our analysis of the sample allows us to confirm that the topic is still relevant today-albeit mature, perhaps; and that there is still a need for additional research. We should point out here that the CSR-reputation relationship is often analyzed in a broader context.

As regards to the nature of the journals, management titles show a greater concern for analyzing companies' financial performance, whilst marketing journals tend to focus on consumer 
reactions to CSR activities. The ethics and corporate governance journals are characterized by more varied themes. In terms of the methodology used, quantitative and conceptual articles are predominant.

From the content analysis we can conclude that the theoretical approach used to analyze the CSR-reputation relationship is very heterogeneous. Although all the theories seem to acknowledge the existence of an information asymmetry problem and the agency relationship, it would appear that the Stakeholders Theory and Resource-Based Theory are the most frequently used. Moreover, a good amount of existing research combines several theories. On the whole, the empirical results are conclusive in demonstrating a positive relationship between CSR initiatives and brand value. Conversely, the relationship between CSR and financial performance has not always proved so conclusive. This relationship appears possible depending on the variables included in the general model — and on the operationalization of the variables, which can alter results.

As a compendium of the analysis it was possible to propose a reference model in the form of hypotheses which considers a direct relationship between CSR and corporate reputation and between CSR and financial value of the company. Furthermore, reputation also affects brand value and enhances financial value. This model is shown in Figure 1.

Delving deeper into the context of family businesses we have found a much smaller body of literature, however. To date, far fewer authors who have studied the links between CSR and reputation in family firms than in other contexts. Moreover, while explicitly or implicitly recognizing some of the relationships in the general model (Figure 1), the theoretical framework varies. 
Figure 1. Proposed research model: the CSR-reputation relationship

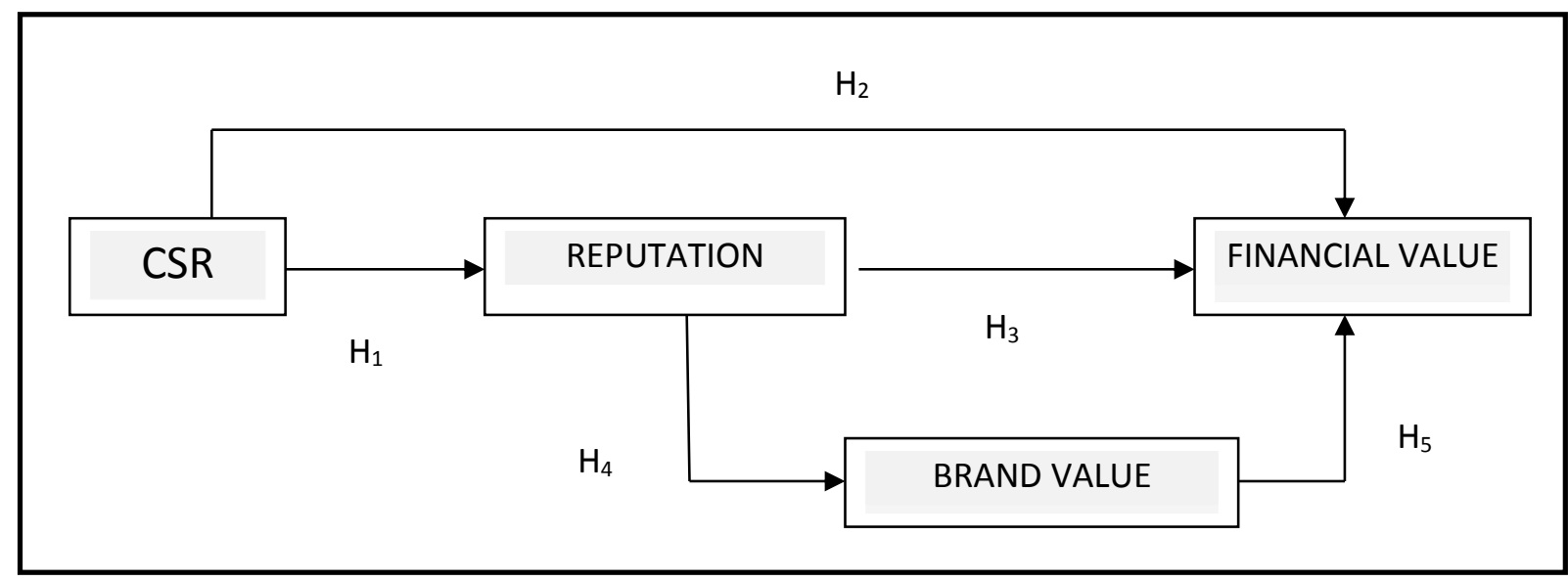

Source: Own elaboration

The management style and characteristics of many family businesses themselves make it advisable to take into account aspects such as their strong link with local communities of reference, the transmission of values—-such as integrity and honesty—and a notable interest in preserving brand / family reputation. Hence, the generalist theories identified in the first part of this article - based, on the whole, on maximization of economic criteria principles - seem to lose their validity; and the need arises for other approaches with which to consider these peculiarities. This explains why Stewardship Theory and Socioemotional Wealth Theory emerge as recommended, predominant approaches in the specialized literature. These proposals consider collective, emotional objectives rather than individual, merely economic goals.

Hence, in conclusion — and considering potential lines of future research-we consider that:

- While the topic is relatively mature in the general context, in the context of family businesses there is room for a considerable number of new contributions that take into account both comparative studies of family versus non-family businesses, and research considering the heterogeneity of family businesses themselves. 
-The analysis of the proposed relationships in our general model—individually or jointlywould be of great theoretical and practical interest, fostering a better understanding of the extent to which CSR actions actually have an impact on the reputation, image and financial value of family businesses. Even international and cross-cultural studies would enrich the literature significantly (the fact is, we have not found any evidence of cross-cultural research on the topic).

- An evaluation of the reactions of each of the different stakeholders regarding CSR actions by family firms would also be of great interest. The greater proximity that seems to exist between these companies and their interest groups could lead to results that are slightly different than those obtained in the generalist literature.

- From a methodological point of view, it is possible to approach the study using both qualitative and quantitative tools. We should note here the need to adapt generalist theories and to consider others that seem to be a better fit to the peculiarities of the context.

Finally, despite being a clear contribution to the literature, we are aware that this study is not without its limitations. Firstly, the results may have been marginally different if the search criteria — journals and keywords — had been altered. With a view to minimize this shortcoming and ensure the reliability and replicability of the study, we followed the steps recommended by Kitchenham et al. (2009) and Baumann et al. (2002) in preparing this article. Moreover, the journals chosen for the purpose of this study reflect the results of a survey carried out amongst specialized investigators of international repute. We also observed various trends that allowed us to identify topics of interest. Furthermore, due to the time period of the analysis, the search results may have been modified slightly, as articles could have potentially been under revision or in the pre-publication stage. Finally, content analysis is subject to a certain degree of 
subjectivity, which we have tried to minimize by developing a complete database. In the future it would desirable to collaborate with other investigators who developed their own codification process in order to discuss conclusions and reach a consensus. In any event, the aforementioned limitations are to be expecting when carrying out systematic literature reviews.

\section{References}

Aguilera, Ruth V., Deborah E. Rupp, Cynthia A. Williams, and Jyoti Ganapathi. 2007. "Putting the Sback in corporate social responsibility: a multilevel theory of social change in organizations." Academy of Management Review 32:836-863.

Aoi, Michikazu, Shigeru Asaba, Keiichi Kubota, and Hitoshi Takehara. 2015. "Family firms, firm characteristics, and corporate social performance: A study of public firms in Japan." Journal of Family Business Management 5:192-217.

Aouadi, Amal, and Sylvain Marsat. 2016. "Do ESG Controversies Matter for Firm Value? Evidence from International Data." Journal of Business Ethics 1-21. Accessed February 2017. doi: 10.1007/s10551-016-3213-8.

Axjonow, Anastasia, Jürgen Ernstberger, and Christiane Pott. 2016. "The impact of corporate social responsibility disclosure on corporate reputation: A non-professional stakeholder perspective." Journal of Business Ethics 1-22. doi:10.1007/s10551-016-3225-4.

Barnea, Amir, and Amir Rubin. 2010. "Corporate social responsibility as a conflict between shareholders." Journal of Business Ethics 97:71-86.

Barney, Jay. 1991. "Firm resources and sustained competitive advantage." Journal of Management 17:99-120.

Basil, Debra Z., Mary S. Runte, M. Easwaramoorthy, and Cathy Barr. 2009. "Company support for employee volunteering: a national survey of companies in Canada." Journal of Business Ethics $85: 387-398$

Baumann, H., Frank Boons, and Annica Bragd. 2002. "Mapping the green product development field: engineering, policy and business perspectives." Journal of Cleaner Production 10:409-425.

Bear, Stephen, Noushi Rahman, and Corinne Post. 2010. "The impact of board diversity and gender composition on corporate social responsibility and firm reputation." Journal of Business Ethics 97:207-221 
Beliveau, Barbara, Melville Cottrill, and Hugh M. O'Neill. 1994. "Predicting corporate social responsiveness: a model drawn from three perspectives." Journal of Business Ethics 13:731-738.

Benavides-Velasco, Carlos, Cristina Quintana-García, and Vanesa Guzmán-Parra. 2013. "Trends in family business research.” Small Business Economics 40:41-57.

Berrone, Pascual, Cristina Cruz, and Luis R. Gomez-Mejia. 2012. "Socioemotional wealth in family firms: Theoretical dimensions, assessment approaches, and agenda for future research." Family Business Review 253:258-279.

Binz Claudia, Joseph Hair, Torsten M. Pieper, and Artur Baldauf. 2013. "Exploring the effect of distinct family firm reputation on consumers' preferences." Journal of Family Business Strategy 4:3-11.

Block, Joem, and Marcus Wagner. 2014. "Ownership versus management effects on corporate social responsibility concerns in large family and founder firms." Journal of Family Business Strategy 5:339-346.

Block, Joem, and Marcus Wagner. 2013. "The effect of family ownership on different dimensions of corporate social responsibility: evidence from large US firms." Business Strategy and the Environment 23:475-792.

Brown, Tom J. and Peter A. Dacin. 1997. "The company and the product: corporate associations and consumer product responses.” Journal of Marketing 61:68-84.

Campopiano, Giovanna, and Alfredo De Massis. 2015. "Corporate social responsibility reporting: A content analysis in family and non-family firms". Journal of Business Ethics 129:511-534.

Castelo, Manuel Branco, and Lúcia Lima Rodrigues. 2006. "Corporate social responsibility and resource-based perspectives". Journal of Business Ethics 69:111-132.

Chan, Yolanda, and Eric Ngai. 2011. "Conceptualising electronic word of mouth activity: An inputprocess-output perspective." Marketing Intelligence \& Planning 29:488-516.

Chen, Yubo Shankar Ganesan, and Yong Liu. 2009. "Does a firm's product-recall strategy affect its financial value? An examination of strategic alternatives during the product-harm crises." Journal of Marketing 73:214-226.

Clarke, Monica, and Gibson-Sweet. 1999. "The use of corporate social disclosure in the management of reputation and legitimacy: a cross sectorial analysis of UK top 100 companies." Business Ethics: A European Review 8:5-13.

Cui, Victor, Shujun Ding, Mingzhi Liu, and Zhenyu Wu. 2017. "Revisiting the effect of family involvement on corporate social responsibility: a behavioural agency perspective." Journal of Business Ethics, 1-19. doi:10.1007/s10551-016-3309-1.

Dahlsrud, Alexander. 2008. "How corporate social responsibility is defined: an analysis of 37 definitions." Corporate social responsibility and environmental management 15 (1): 1-13. 
Déniz, María de la Cruz, and Ma Katiuska Cabrera Suárez. 2005. "Corporate social responsibility and family business in Spain.” Journal of Business Ethics 56:27-41.

DiMaggio, Paul J., and Walter W. Powell. 1983. "The iron cage revisited: institutional isomorphism and collective rationality in organizational fields." American Sociological Review 48:147-160.

Doh, Jonathan P., Shawn D. Howton, Shelly W. Howton, and Donald S. Siegel. 2010. "Does the market respond to an endorsement of social responsibility? The role of institutions, information and legitimacy." Journal of Management 36:1461-1485.

Du, Shuili Du., C.B. Bhattacharya, and Sankar Sen. 2007. "Reaping relational rewards from corporate social responsibility: the role of competitive positioning." International Journal of Research in Marketing 24:224-241.

Dubbink, Wim, Johan Graafland, and Luc van Liedekerke. 2008. "CSR, transparency and the role of intermediate organizations.” Journal of Business Ethics 82:391-406.

Eberle, David, Guido Berens, and Ting Li. 2013. "The Impact of interactive corporate social responsibility communication on corporate reputation." Journal of Business Ethics 118:731-746.

Ellen, Pam Scholder, Deborah J. Webb, and Lois A. Mohr. 2006. "Building corporate associations: Consumer attributions for corporate socially responsible programs." Journal of the Academy of Marketing Science 34:147-157.

Freeman, R. Edward. 1984. Strategic management: a stakeholder perspective. Englewood Cliffs: Prentince Hall.

Faller, Christian M., and Dodo zu Knyphausen-Aufseß. 2016. "Does equity ownership matter for corporate social responsibility? A literature review of theories and recent empirical findings." Journal of Business Ethics (March): 1-16. doi:10.1007/s10551-016-3122-x

Fitzgerald, Margaret A., George W. Haynes, Holly L. Schrank, and Sharon M. Danes. 2010. "Socially responsible processes of small family business owners: exploratory evidence from the National Family Business Survey.” Journal of Small Business Management 48:524-551.

Fombrun, Charles. 2001. "Corporate reputation as economic assets." In The Blackwell Handbook of Strategic Management, edited by Hitt, M., Freeman R., and Harrison F. Malden: Ed. Blackwell Publishers.

Fombrun, Charles, and Mark Shanley. 1990. "What's in a Name? Reputation building and corporate strategy." Academy of Management Journal 33:233-258.

Francés, Pedro, and Andrés del Río. 2008. "Stakeholder’s preference and rational compliance: a comment on Sacconi's CSR as a model for extended corporate governance: compliance, reputation and reciprocity.” Journal of Business Ethics 82:59-76 
Friedman, Milton. 1970. "The social responsibility of business is to increase its profits." New York Times $13: 122-126$.

Gardberg, Naomi A., and Charles J. Fombrun. 2006. "Corporate citizenship: creating intangible assets across institutional environments." Academy of Management Review 31:329-346.

Godfrey, Paul C., Craig B. Merrill, and Jared M. Hansen. 2009. "The relationship between corporate social responsibility and shareholder value: an empirical test of the risk management hypothesis." Strategic Management Journal 30:425-445.

Godfrey, Paul C. 2005. "The relationship between corporate philanthropy and shareholder wealth: a risk management perspective." Academy of Management Review 30:777-798.

Hadani, Michael, and Susan Coombes. 2015. "Complementary relationships between corporate philanthropy and corporate political activity: an exploratory study of political marketplace contingencies.” Business \& Society 54:859-881.

Harjoto, Maretno A., and Hoje Jo. 2011. "Corporate governance and CSR nexus." Journal of Business Ethics 100:45-67.

Holzer, Boris. 2008. "Turning stakeseekers into stakeholders: a political coalition perspective on the politics of stakeholders influence.” Business \& Society 47:50-67.

Hond, Frank den, Kathleen A. Rehbein, Frank G. A. de Bakker, and Hilde Kooijmans-van Lankveld. 2014. "Playing on two chessboards: Reputation effects between corporate social responsibility CSR and corporate political activity CPA.”Journal of Management Studies 51:790-813.

Hsu, Ker-Tah. 2012. "The advertising effects of corporate social responsibility on corporate reputation and brand equity: evidence from the life insurance industry in Taiwan." Journal of Business Ethics 109:189-201

Hur, Won-Moo, Hanna Kim, and Jeong Woo. 2014. "How CSR leads to corporate brand equity: mediating mechanisms of corporate brand credibility and reputation." Journal of Business Ethics $125: 75-86$

Ingenhoff, Diana, and A. Martina Koelling. 2012. "Media governance and corporate social responsibility of media organizations: an international comparison." Business Ethics: a European Review 21:154-167.

Jackson, Charles, and Torben Bundgard. 2002. "Achieving quality in social reporting: the role of surveys in stakeholder consultation." Business Ethics: A European Review 11:253-259.

Jadhi, Khosro S., and Gaye Acikdilli. 2009. "Marketing communications and corporate social responsibility: marriage of convenience or shotgun wedding?" Journal of Business Ethics 88:103113. 
Janney, Jay J., and Steve Gove. 2011. "Reputation and corporate social responsibility aberrations, trends and hypocrisy: reactions to firms choices in the stock option backdating scandal." Journal of Management Studies 48:1462-1585.

Jones, Thomas. 1995. "Instrumental stakeholder theory: a synthesis of ethics and economics." Academy of Management Review 20:404-437.

Kim, Sora. 2014. "What's worse in times of product-harm crisis? Negative corporate ability or negative CSR reputation?" Journal of Business Ethics 123:157-170.

Kim, Soo-Yeon, and Hyojung Park. 2011. "Corporate social responsibility as an organization attractiveness for prospective public relations." Journal of Business Ethics 103:639-653.

Kitchenham, Barbara, Pearl Brereton, David Budgen, Mark Turner, John Bailey, and Stephen Linkman. 2009. "Systematic literature reviews in software engineering: a systematic literature review." Information and Software Technology 51:7-15.

Labelle, Réal, Taïeb Hafsi, Claude Francoeur, and Walid Ben Amar. 2015. "Family firms' corporate social performance: a calculated quest for socioemotional wealth." Journal of Business Ethics (Dec): 1-15. doi:10.1007/s10551-015-2982-9.

Laguir, Issam, Lamia Laguir, and Jamal Elbaz. 2016. "Are family small- and medium-sized enterprises more socially responsible than nonfamily small- and medium-sized enterprises?" Corporate Social Responsibility and Environmental Management 23:386-398.

Lai, Chi-Shiun, Chih-Jen Chiu, Chin-Fang Yang, and Da-Chang Pai. 2010. "The effects of corporate social responsibility on brand performance: the mediating effect of industrial brand equity and corporate reputation." Journal of Business Ethics 95:457-469.

Lii, Yuan-Shuh, and Monle Lee. 2012. "Doing right leads to doing well: when the type of CSR and reputation interact to affect consumer evaluations of the firm". Journal of Business Ethics 105:6981.

Liston-Heyes, Catherine, and Gwen Ceton. 2009. "An investigation of real versus perceived CSP in S\&P-500 firms.” Journal of Business Ethics 89:283-296.

Marques, Pilar, Pilar Presas, and Alexandra Simon. 2014. "The heterogeneity of family firms in CSR engagement." Family Business Review 27:206-227

McWilliams, Abagail, and Donald Siegel. 2001. "Corporate social responsibility: a theory of the firm perspective." Academy of Management Review 26:117-127.

McWilliams, Abagail, and Donald Siegel. 2000. "Corporate social responsibility and financial performance: correlation or misspecification.” Strategic Management Journal 21:603-609. 
Morsing, Mette, and Majken Schultz. 2006. "Corporate social responsibility communication: stakeholder information, response and involvement strategies." Business Ethics: a European Review 15:323-338.

Mueller, Martin, Virginia Gomes dos Santos, and Stefan Seuring. 2009. "The contribution of environmental and social standards towards ensuring legitimacy in supply chain governance." Journal of Business Ethics 89:509-523.

Muller, Alan, and Ans Kolk. 2015. "Responsible tax as corporate social responsibility: the case of multinational enterprises and effective tax in India." Business \& Society 54:435-463.

Niehm, Linda S., Jane Swinney, and Nancy J. Miller. 2008. "Community social responsibility and its consequences for family business performance.” Journal of Small Business Management 46:331350.

Nikolaeva, Ralitza, and Marta Bicho. 2011. "The role of institutional and reputational factors in the voluntary adoption of corporate social responsibility reporting standards." Journal of the Academy of Marketing Science 39:136-157.

Orlitzky, Marc. 2011. "Institutional logics in the study of organizations: the social construction of the relationship between corporate social and financial performance.” Business Ethics Quarterly 21:409-444.

Orlitzky, Marc, Donald S. Siegel, and David A. Waldman. 2011. "Strategic corporate social responsibility and environmental sustainability." Business \& Society 50:6-27.

Orlitzky, Marc, and John D. Benjamin. 2001. "Corporate social performance and firm risk: a metaanalytic review." Business \& Society 24:403-441.

Peloza, John, and Jingzhi Shang. 2011. "How can corporate social responsibility activities create value for stakeholders? A systematic review." Journal of the Academy of Marketing Science 39:117135.

Pérez, Andrea, María del Mar García de los Salmones, and Carlos López. 2015. "Corporate reputation in the Spanish context: an interaction between reporting to stakeholders and industry." Journal of Business Ethics 129:733-746.

Porter, Michael E., and Mark R. Kramer. 2006. "Strategy \& society: the link between competitive advantage and corporate social responsibility." Harvard Business Review 84:78-92.

Rettab, Belaid, Anis Ben Brik, and Kamel Mellahi. 2009. "A Study of management perceptions of the impact of corporate social responsibility on organisational performance in emerging economies: the case of Dubai." Journal of Business Ethics 89:371-390.

Roberts, Peter W., and Grahame R. Dowling. 2002. "Corporate reputation and sustained superior financial performance." Strategic management journal 23:1077-1093. 
Rousseau, Denise, Joshua Manning, and David Denyer. 2008. "Evidence in management and organizational science: assembling the field's full weight of scientific knowledge through syntheses." The Academy of Management Annals 2:475-515.

Sacconi, Lorenzo. 2007. "A social contract account for CSR as an extended model of corporate governance: compliance, reputation and reciprocity.” Journal of Business Ethics 75:77-96.

Scholder, Pam Ellen, Deborah J. Webb, and Lois A. Mohr. 2006. "Building corporate associations: consumer attributions for corporate socially responsible programs." Journal of the Academy of Marketing Science 34:147-157.

Sen, Sankar, and Chitra B. Bhattacharya. 2001. "Does doing good always lead to doing better? Consumer reactions to corporate social responsibility." Journal of Marketing Research 38:225243.

Siltaoja, Marjo Elisa. 2006. "Value priorities as combining core factors between CSR and reputation: a qualitative study.” Journal of Business Ethics 68:91-111.

Skard, Siv, and Helge Thorbjørnsen. 2014. "Is publicity always better than advertising? The role of brand reputation in communicating corporate social responsibility." Journal of Business Ethics 124:149-160.

Stanaland, Andrea J., May O. Lwin, and Patrick E. Murphy. 2011. "Consumer perceptions of the antecedents and consequences of corporate social responsibility." Journal of Business Ethics 102:47-55.

Stoian, Carmen, and Mark Gilman. 2017. "Corporate social responsibility that "Pays": A strategic approach to CSR for SMEs." Journal of Small Business Management 55:5-31.

Stuebs, Marty, and Li Sun. 2010. "Business reputation and labor efficiency, productivity, and cost." Journal of Business Ethics 96:265-283.

Taneja, Shallini S., Pawan Kumar Taneja, and Rajen K. Gupta. 2011. "Researches in corporate social responsibility: A review of shifting focus, paradigms, and methodologies." Journal of Business Ethics 101:343-364.

Tetrault Sirsly, Carol-Ann, and Elena Lvina. 2016. "From Doing Good to Looking Even Better: The Dynamics of CSR and Reputation.” Business \& Society. (Feb). doi:10.1177/0007650315627996

Torres, Anna, Tammo H.A. Bijmolt, Josep A. Tribó, and Peter Verhoef. 2012. "Generating global brand equity through corporate social responsibility to key stakeholders." International Journal of Research in Marketing 29:13-24.

Tranfield, David, David Denyer, and Palminder Smart. 2003. "Towards a methodology for developing evidence-informed management knowledge by means of systematic review." British Journal of Management 14:207-22. 
Tuck, Eng Cheah, Wen Li Chan, and Corinne Lin Chieng. 2007. "The corporate social responsibility of pharmaceutical product recalls: an empirical examination of U.S. and U.K. markets." Journal of Business Ethics 76:427-449.

Vanhamme, Joëlle, and Bas Grobben. 2009. "Too good to be true! The effectiveness of CSR history in countering negative publicity." Journal of Business Ethics 85:273-283.

Van de Ven, Bert, and Ronald Jeurissen. 2005. "Competing responsibly." Business Ethics Quarterly 15:299-317.

Van Gils, Anita, Clay Dibrell, Donald O. Neubaum, and Justin B. Craig. 2014. "Social issues in the family enterprise." Family Business Review 27:193-205.

Vázquez-Carrasco, Rosario, and María Eugenia López-Pérez. 2013. "Small \& medium-sized enterprises and Corporate Social Responsibility: a systematic review of the literature." Quality \& Quantity, International Journal of Methodology 47:3205-3218.

Vidaver-Cohen, Deborah, and Peggy Simcic Brønn. 2015. "Reputation, responsibility, and stakeholder support in Scandinavian firms: a comparative analysis." Journal of Business Ethics 127:49-64.

Walker, Matthew, Bob Heere, Milena M. Parent, and Dan Drane. 2010. "Social responsibility and the Olympic Games: the mediating role of consumer attributions." Journal of Business Ethics 95:659680.

Wagner, Tillmann, Richard J. Lutz, and Barton A. Weitz. 2009. "Corporate hypocrisy: overcoming the threat of inconsistent corporate social responsibility perceptions." Journal of Marketing 73:7791.

Yusof, Mohar, Leilanie Mohd Nor, and James Edward Hoopes. 2014. "Virtuous CSR: an Islamic family business in Malaysia." Journal of Family Business Management 4:133-148.

Zientara, Piotr. 2015. "Socioemotional Wealth and Corporate Social Responsibility: A critical analysis." Journal of Business Ethics, (Sept.): 1-15. doi:10.1007/s10551-015-2848-1.

This is an Open Access article distributed under the terms of the Creative Commons Attribution-Non-Commercial-No Derivatives License (http://creativecommons.org/licenses/by-nc-nd/4.0/), which permits non-comercial re-use and distribution, provided the original work is properly cited, and is not altered or transformed in any way. 


\section{Journal of Evolutionary Studies in Business}

Appendix 1. Investigations that analyze the CSR/ reputation-financial value relationship (related hypotheses)

\begin{tabular}{|c|c|c|c|c|}
\hline Authors (Year) & Hypotheses & Sample & Methodology & Results \\
\hline Beliveau et al. (1994) & $\begin{array}{l}\mathrm{H}_{3} \text { : The company market share is directly related to the CSR level of } \\
\text { the company }\end{array}$ & $\begin{array}{l}\text { Fortune Annual } \\
\text { Survey of Corporate } \\
\text { Reputation }\end{array}$ & Regression & $\mathrm{H}_{3}$ is confirmed \\
\hline $\begin{array}{l}\text { Clarke and Gibson-Sweet } \\
\text { (1999) }\end{array}$ & $\begin{array}{l}\text { RQ: Assessment of the CSR report as a means of managing reputation } \\
\text { and legitimacy }\end{array}$ & $\begin{array}{l}100 \text { top companies in } \\
\text { the U.K. }\end{array}$ & $\begin{array}{l}\text { Content analysis of } \\
\text { reports }\end{array}$ & $\begin{array}{l}\text { The importance of annual reports as a } \\
\text { means of legitimacy and reputation } \\
\text { management }\end{array}$ \\
\hline Doh et al. (2010) & $\begin{array}{l}\mathrm{H}_{1(\mathrm{a})} \text { : Companies included in a social index will generate a positive } \\
\text { effect }\end{array}$ & $\begin{array}{lll}\text { Índices } & \text { Calver } \& \\
\text { Domini } & & \\
\end{array}$ & Analysis of events & $\mathrm{H}_{1(\mathrm{a})}$ is rejected \\
\hline Holzer (2008) & $\begin{array}{l}\text { RQ: The consideration of organizations and stakeholders with regard } \\
\text { to CSR }\end{array}$ & Royal Dutrch/ Shell & Case study & $\begin{array}{l}\text { CSR as a means of preventing conflicts that } \\
\text { reinforces the reputation and contributes to } \\
\text { the value of the company }\end{array}$ \\
\hline Hsu (2012) & $\mathrm{H}_{2}$ : CSR initiatives improve reputation & $\begin{array}{l}\text { Life insurance } \\
\text { companies in Taiwan }\end{array}$ & Structural equations & $\mathrm{H}_{2}$ is accepted \\
\hline Godfrey et al. (2009) & $\begin{array}{l}\mathrm{H}_{1} \text { : Shareholder value is less affected following an negative event for } \\
\text { those companies that practice CSR }\end{array}$ & $\begin{array}{l}160 \text { companies } \\
\text { selected from the } \\
\text { Socrates Database }\end{array}$ & Econometric models & $\mathrm{H}_{2}$ is accepted \\
\hline Janney and Gove (2011) & $\begin{array}{l}\mathrm{H}_{2}: \text { The global CSR initiatives lessen the negative impact following } \\
\text { the announcement of a scandal }\end{array}$ & $\begin{array}{l}\text { Wall Street Journal } \\
\text { scorecard of firms }\end{array}$ & Analysis of events & $\mathrm{H}_{2}$ is accepted \\
\hline Lai et al. (2010) & $\begin{array}{l}\mathrm{H}_{3}: \text { The perception of CSR is directly related to the performance of } \\
\text { the company } \\
\text { H5: The corporate reputation is directly related to the performance of } \\
\text { the company }\end{array}$ & Firms in Taiwan & Structural equations & $\mathrm{H}_{3}$ and $\mathrm{H}_{5}$ are accepted \\
\hline Rettab et al. (2009) & $\begin{array}{l}\mathrm{H}_{1}: \text { CSR is not positively related to financial results (in emerging } \\
\text { economies) }\end{array}$ & $\begin{array}{l}\text { Sample of firms in } \\
\text { Dubai }\end{array}$ & Structural equations & $\begin{array}{l}\mathrm{H}_{1} \text { is rejected (that is to say that there is a } \\
\text { relationship between CSR and financial } \\
\text { results) }\end{array}$ \\
\hline Siltaoja (2006) & RQ: Interactions between CSR and reputation & Finnish company & $\begin{array}{l}\text { Case study with in-depth } \\
\text { interviews }\end{array}$ & $\begin{array}{l}\text { Relationships between CSR and reputation } \\
\text { affect the value of company }\end{array}$ \\
\hline Stanaland et al. (2011) & $\begin{array}{l}\mathrm{H}_{1} \text { : There is a relationship between the financial results of the } \\
\text { company and the stakeholder's evaluation of CSR } \\
\mathrm{H}_{6} \text { : Corporate reputation lessens the perceived risk }\end{array}$ & Sample of consumers & Structural equations & $\mathrm{H}_{1}$ and $\mathrm{H}_{6}$ are accepted \\
\hline $\begin{array}{l}\text { Vanhamme and Grobben } \\
\text { (2010) }\end{array}$ & $\begin{array}{l}\mathrm{H}_{1} \text { : The greater the tradition and integrity of CSR the greater the } \\
\text { protection in the event of a crisis }\end{array}$ & Convenience sample & Experimentation & $\mathrm{H}_{1}$ is accepted \\
\hline
\end{tabular}

The works of McWilliams and Siegel (2001), Mueller et al. (2009), Orlitzky et al. (2011) are conceptual studies

\section{Online ISSN: 2385-7137}

http://revistes.ub.edu/index.php/JESB
COPE Committee on Publication Ethics

Creative Commons License 4.0 @ccreative 


\section{Journal of Evolutionary Studies in Business}

Appendix 2. Studies that analyze the relationships between reputation-brand value/brand value-financial value (related hypotheses)

\begin{tabular}{|c|c|c|c|c|}
\hline Authors (year) & Hypotheses & Sample & Methodology & Results \\
\hline Brown and Dacin & $\begin{array}{l}\text { RQ: There is a relationship between CSR and product evaluation by } \\
\text { consumers }\end{array}$ & Consumers & Experimentation & $\begin{array}{l}\text { CSR affects the company reputation } \\
\text { and brand value }\end{array}$ \\
\hline Du et al. (2007) & $\begin{array}{l}\mathrm{H}_{4} \text { : Consumers of a particular brand are more likely to identify } \\
\text { themselves with the brand, be loyal and support the brand when the } \\
\text { company is associated with CSR versus those companies who do not } \\
\text { carry out CSR }\end{array}$ & $\begin{array}{l}\text { Web survey among yogurt } \\
\text { consumers }\end{array}$ & Structural equations & $\mathrm{H}_{4}$ is accepted \\
\hline Hsu (2012) & $\begin{array}{l}\mathrm{H}_{1}: \text { CSR initiatives increase consumer satisfaction } \\
\mathrm{H}_{2}: \text { CSR initiatives improve corporate reputation } \\
\mathrm{H}_{3}: \text { A better corporate reputation will improve the brand value }\end{array}$ & $\begin{array}{l}\text { Insurance companies in } \\
\text { Taiwan }\end{array}$ & Structural equations & $\mathrm{H}_{1}, \mathrm{H}_{2}$ and $\mathrm{H}_{3}$ are accepted \\
\hline $\begin{array}{ll}\text { Jahdi and Acikdilli } \\
(2009)\end{array}$ & RQ: Analysis of the effect of communication for the purpose of CSR & UK bank & Case study & $\begin{array}{l}\text { Transparency in reporting increases the } \\
\text { credibility and reinforces brand value }\end{array}$ \\
\hline Lai et al. (2010) & $\begin{array}{l}\mathrm{H}_{1} \text { : A relationship exists between CSR and brand value } \\
\mathrm{H}_{2} \text { : A relationship exists between CSR and reputation } \\
\mathrm{H}_{4} \text { : Corporate reputation is positively related to brand value } \\
\mathrm{H}_{5} \text { : Corporate reputation is positively related to performance } \\
\mathrm{H}_{6} \text { : Brand value is directly related to company performance }\end{array}$ & Firms in Taiwan & Structural equations & $\mathrm{H}_{1}, \mathrm{H}_{2}, \mathrm{H}_{4}, \mathrm{H}_{5}$ and $\mathrm{H}_{6}$ are accepted \\
\hline $\begin{array}{l}\text { Sen and Battacharya } \\
(2001)\end{array}$ & $\mathrm{H}_{3}$ : CSR initiatives affect the consumer evaluations of the company & MBA students in the USA & Experimentation & $\mathrm{H}_{3}$ is accepted \\
\hline Stanaland et al. (2011) & $\begin{array}{l}\mathrm{H}_{1} \text { : There is a relationship between the financial results of the } \\
\text { company and the consumer evaluation of CSR } \\
\mathrm{H}_{7} \text { : Corporate reputation increases consumer trust } \\
\mathrm{H}_{8 / 9} \text { : Consumer trust decreases the risk perceived/increases loyalty }\end{array}$ & Sample of consumers & Structural equations & $\mathrm{H}_{1}, \mathrm{H}_{7}, \mathrm{H}_{8}$ and $\mathrm{H}_{9}$ are accepted \\
\hline Torres et al. (2012) & $\mathrm{H}_{1}:$ CSR positively affects the brand value & $\begin{array}{l}\text { SGP/ SiRi + Interbrand } \\
\text { Database }\end{array}$ & Econometric models & $\mathrm{H}_{1}$ is accepted \\
\hline Wagner et al. (2009) & $\begin{array}{l}\mathrm{H}_{1} \text { : The perception of hypocrisy in CSR affects the attitudes of } \\
\text { clients toward the company }\end{array}$ & Marketing students & Experimentation & $\mathrm{H}_{1}$ is accepted \\
\hline Walker et al. (2010) & $\begin{array}{l}\mathrm{H}_{3} \text { : Knowledge of CSR positively affects reputation when there are } \\
\text { altruistic contributions but negatively when they are opportunistic } \\
\mathrm{H}_{4} \text { : The reputation positively affects word-of-mouth when there are } \\
\text { altruistic contributions but negatively when they are opportunistic }\end{array}$ & $\begin{array}{l}\text { Attendees of the Olympic } \\
\text { Games in Pekin }\end{array}$ & Structural equations & $\mathrm{H}_{3}$, is rejected and $\mathrm{H}_{4}$ is accepted \\
\hline
\end{tabular}

The work of Van de Ven and Jurissen (2005) is a conceptual study

Source: Own elaboration

\section{Online ISSN: 2385-7137}

http://revistes.ub.edu/index.php/JESB
COPE Committee on Publication Ethics

$$
\text { Creative Commons License } 4.0 \text { @ccreative }
$$

